\title{
Ideas and perspectives: is shale gas a major driver of recent increase in global atmospheric methane?
}

\author{
Robert W. Howarth \\ Department of Ecology and Evolutionary Biology, Cornell University, Ithaca, NY 14853, USA
}

Correspondence: Robert W. Howarth (howarth@cornell.edu)

Received: 10 April 2019 - Discussion started: 23 April 2019

Revised: 11 July 2019 - Accepted: 12 July 2019 - Published: 14 August 2019

\begin{abstract}
Methane has been rising rapidly in the atmosphere over the past decade, contributing to global climate change. Unlike the late 20th century when the rise in atmospheric methane was accompanied by an enrichment in the heavier carbon stable isotope $\left({ }^{13} \mathrm{C}\right)$ of methane, methane in recent years has become more depleted in ${ }^{13} \mathrm{C}$. This depletion has been widely interpreted as indicating a primarily biogenic source for the increased methane. Here we show that part of the change may instead be associated with emissions from shale-gas and shale-oil development. Previous studies have not explicitly considered shale gas, even though most of the increase in natural gas production globally over the past decade is from shale gas. The methane in shale gas is somewhat depleted in ${ }^{13} \mathrm{C}$ relative to conventional natural gas. Correcting earlier analyses for this difference, we conclude that shale-gas production in North America over the past decade may have contributed more than half of all of the increased emissions from fossil fuels globally and approximately one-third of the total increased emissions from all sources globally over the past decade.
\end{abstract}

\section{Introduction}

Methane is the second most important greenhouse gas behind carbon dioxide causing global climate change, contributing approximately $1 \mathrm{~W} \mathrm{~m}^{-2}$ to warming when indirect effects are included compared to $1.66 \mathrm{~W} \mathrm{~m}^{-2}$ for carbon dioxide (IPCC, 2013). Unlike carbon dioxide, the climate system responds quickly to changes in methane emissions, and reducing methane emissions could provide an opportunity to immediately slow the rate of global warming (Shindell et al., 2012) and perhaps meet the United Nations Framework
Convention on Climate Change (UNFCCC) COP21 target of keeping the planet well below $2{ }^{\circ} \mathrm{C}$ above the pre-industrial baseline (IPCC, 2018). Methane also contributes to the formation of ground-level ozone, with large adverse consequences for human health and agriculture. Considering these effects as well as climate change, Shindell (2015) estimated that the social cost of methane is 40 to 100 times greater than that for carbon dioxide: USD 2700 per ton for methane compared to USD 27 per ton for carbon dioxide when calculated with a $5 \%$ discount rate and USD 6000 per ton for methane compared to USD 150 per ton for carbon dioxide when calculated with a $1.4 \%$ discount rate.

Atmospheric methane levels rose steadily during the last few decades of the 20th century before leveling off for the first decade of the 21 st century. Since 2008, however, methane concentrations have again been rising rapidly (Fig. 1a). This increase, if it continues in coming decades, will significantly increase global warming and undercut efforts to reach the COP21 target (Nisbet et al., 2019). The total atmospheric flux of methane for the period 2008-2014 was $\sim 24.7 \mathrm{Tg}$ per year greater than for the 2000-2007 period (Worden et al., 2017), an increase of $7 \%$ in global human-caused methane emissions. The change in the stable carbon $\delta^{13} \mathrm{C}$ ratio of methane in the atmosphere over the past 35 years is striking and seems clearly related to the change in the methane concentration (Fig. 1b). For the final 20 years of the 20th century, as atmospheric methane concentrations rose, the isotopic composition became more enriched in the heavier stable isotope of carbon, ${ }^{13} \mathrm{C}$, relative to the lighter and more abundant isotope, ${ }^{12} \mathrm{C}$, resulting in a less negative $\delta^{13} \mathrm{C}$ signal. The isotopic composition remained constant from 1998 to 2008, when the atmospheric concentration was constant. And the isotopic composition has be- 

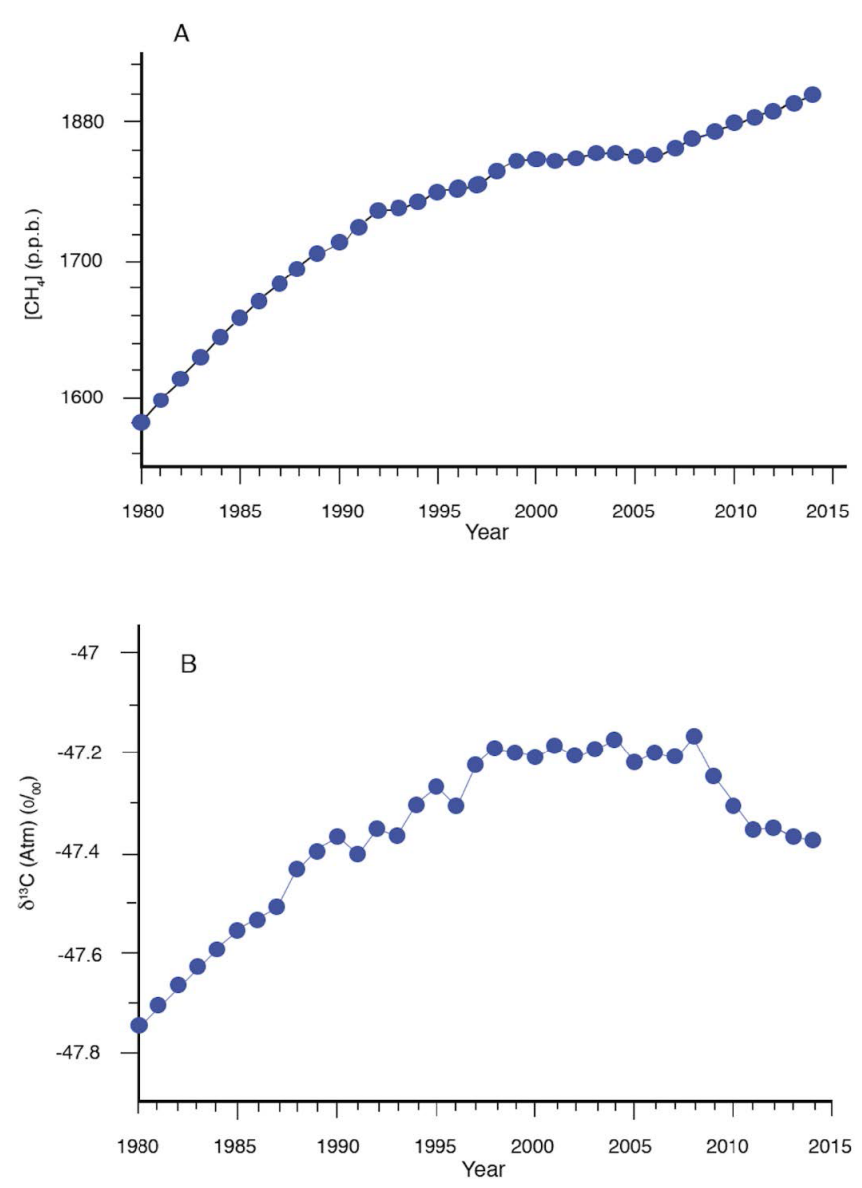

Figure 1. (a) Global increase in atmospheric methane between 1980 and 2015. (b) Change in $\delta^{13} \mathrm{C}$ value of atmospheric methane globally between 1980 and 2015. Both adapted from Schaefer et al. (2016).

come lighter (depleted in ${ }^{13} \mathrm{C}$, more negative $\delta^{13} \mathrm{C}$ ) since 2009 , as atmospheric methane concentrations have been rising again (Schaefer et al., 2016; Nisbet et al., 2016). Since biogenic sources of methane are lighter than the methane released from fossil-fuel emissions, Schaefer et al. (2016) concluded that the increase in atmospheric methane in the late 20th century was due to increasing emissions from fossil fuels but that the increase in methane since 2006 is due to biogenic sources, most likely tropical wetlands, rice culture, or animal agriculture. Their model results indicated that fossil-fuel sources have remained flat or decreased globally since 2006, playing no major role in the recent atmospheric rise of methane. Schaefer et al. (2016) noted that their conclusion contradicted many reports of increased emissions from fossil-fuel sources over this time and stated that their conclusion was "unexpected, given the recent boom in unconventional gas production and reported resurgence in coal mining and the Asian economy". Six months after the Schaefer et al. (2016) study was published in Science, Schwietzke et al. (2016) presented a similar analysis in Nature that used a larger and more comprehensive data set for the $\delta^{13} \mathrm{C}$ values of methane emission sources. They too concluded that fossilfuel emissions have likely decreased during this century and that biogenic emissions are the probable cause of any recent increase in global methane emissions.

\section{Sensitivity of emission models based on $\delta^{13} \mathrm{C}$ in methane to biomass burning}

Model analyses that use $\delta^{13} \mathrm{C}$ methane data to infer emission sources are highly sensitive to changes in the rate of biomass burning: although biomass burning is a relatively small contributor to global methane emissions, those emissions are quite enriched in ${ }^{13} \mathrm{C}$ relative to the atmospheric methane signal (Rice et al., 2016; Sherwood et al., 2017). Both Schaefer et al. (2016) and Schwietzke et al. (2016) assumed that biomass burning had been constant in recent years. However, Worden et al. (2017) estimated that biomass burning globally went down for the period 2007-2014 compared to 2001-2006, resulting in decreased methane emissions of $3.7 \mathrm{Tg}$ per year $( \pm 1.4 \mathrm{Tg}$ per year $)$ and contributing to a lower $\delta^{13} \mathrm{C}$ for atmospheric methane. Using the data set of Schwietzke et al. (2016) for $\delta^{13} \mathrm{C}$ values of methane emission sources, but including changes in biomass burning over time, Worden et al. (2017) concluded that the recent increase in methane emissions was likely driven more by fossil fuels than by biogenic sources, with an increase of $16.4 \mathrm{Tg}$ per year from fossil fuels $( \pm 3.6 \mathrm{Tg}$ per year) compared to an increase of $12 \mathrm{Tg}$ per year from biogenic sources $( \pm 2.5 \mathrm{Tg}$ per year) when comparing 2007-2014 to 2001-2006.

Clearly global models for partitioning methane sources based on the $\delta^{13} \mathrm{C}$ approach are sensitive to assumptions about seemingly small terms such as decreases in biomass burning. In this paper, we explore for the first time another assumption: that the global increase in shale-gas development may have caused some of the depletion of ${ }^{13} \mathrm{C}$ in the global average methane observed over the past decade. Shale-gas emissions were not explicitly considered in the models presented by Schaefer et al. (2016) and Worden et al. (2017) and were explicitly excluded in the analysis of Schwietzke et al. (2016).

\section{What is shale gas?}

Shale gas is a form of unconventional natural gas (mostly methane) held tightly in shale-rock formations. Conventional natural gas, the dominant form of natural gas produced during the 20th century, is composed largely of methane that migrated upward from the underlying sources such as shale rock over geological time, becoming trapped under a geological seal (Fig. 2a). Until this century, shale gas was not commercially developable. The use of a new combination of technologies in the 21st century - high-precision directional drilling, high-volume hydraulic fracturing, and clus- 


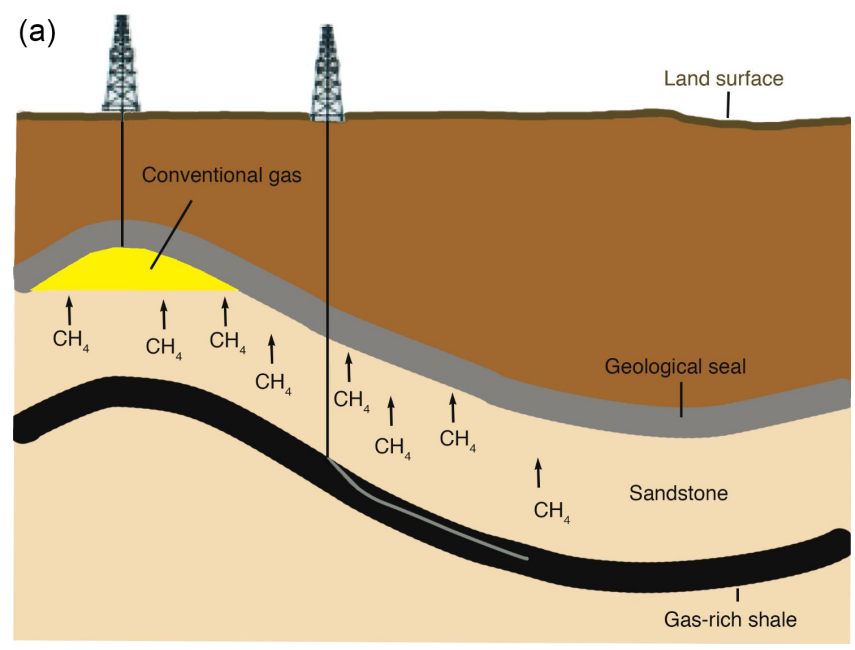

(b)

Global Production of Natural Gas 2000-2017 with projection to 2040

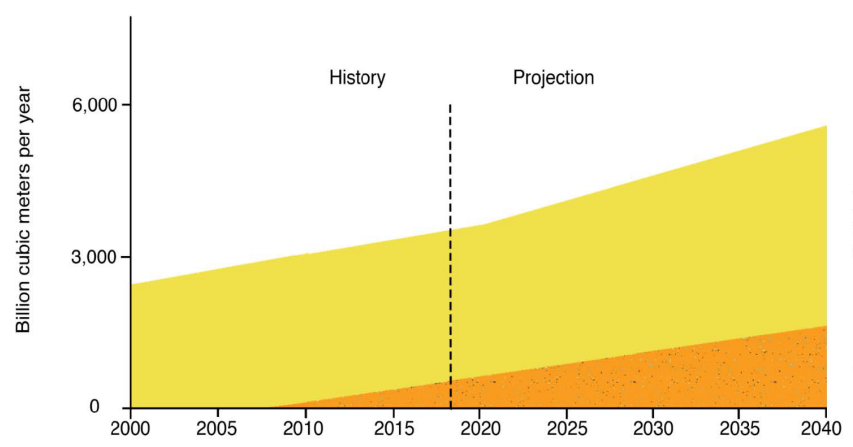

Figure 2. (a) Schematic comparing shale gas and conventional natural gas. For conventional natural gas, methane migrates from the shale through semipermeable formations over geological time, becoming trapped under a geological seal. Shale gas is methane that remained in the shale formation and is released through the combined technologies of high-precision directional drilling and highvolume hydraulic fracturing. (b) Global production of shale gas and other forms of natural gas from 2000 to 2017, with projections into the future from EIA (2016). Redrawn from EIA (2016) with data from IEA (2017).

tered multi-well drilling pads - has changed this. In recent years, global shale-gas production has exploded 14-fold, from 31 billion cubic meters per year in 2005 to 435 billion cubic meters per year in 2015 (Fig. 2b), with $89 \%$ of this production in the United States and $10 \%$ in western Canada (EIA, 2016). Shale gas accounted for $63 \%$ of the total increase in natural gas production globally over this time period (EIA, 2016; IEA, 2017). The US Department of Energy predicts rapid further growth in shale-gas production globally, reaching 1500 billion cubic meters per year by 2040 (EIA, 2016; Fig. 2b).
Several studies have suggested that the $\delta^{13} \mathrm{C}$ signal of methane from shale gas can often be lighter (more depleted in ${ }^{13} \mathrm{C}$ ) than that from conventional natural gas (Golding et al., 2013; Hao and Zou, 2013; Turner et al., 2017; Botner et al., 2018). This should not be surprising. In the case of conventional gas, the methane has migrated over geological time frames from the shale and other source rocks through permeable strata until trapped below a seal (Fig. 2a). During this migration, some of the methane can be oxidized both by bacteria, perhaps using iron (III) or sulfate as the source of the oxidizing power, and by thermochemical sulfate reduction (Whelan et al., 1986; Burruss and Laughrey, 2010; Rooze et al., 2016). This partial oxidation fractionates the methane by preferentially consuming the lighter ${ }^{12} \mathrm{C}$ isotope and gradually enriching the remaining methane in ${ }^{13} \mathrm{C}$ (Hao and Zou, 2013; Baldassare et al., 2014), resulting in a $\delta^{13} \mathrm{C}$ signal that is less negative. The methane in shales, on the other hand, is tightly held in the highly reducing rock formation and therefore very unlikely to have been subject to oxidation and the resulting fractionation. The expectation, therefore, is that methane in conventional natural gas should be heavier and less depleted in ${ }^{13} \mathrm{C}$ than the methane in shale gas.

\section{Calculating the effect of ${ }^{13} \mathrm{C}$ signal of shale gas on emission sources: conceptual framework}

To explore the contribution of methane emissions from shale gas, we build on the analysis of Worden et al. (2017). Figure 3a shows the $\delta^{13} \mathrm{C}$ values used by them as well as their mean estimates for changes in emissions since 2008 (as they estimated using the $\delta^{13} \mathrm{C}$ data of Schwietzke et al., 2016). Figure $3 \mathrm{a}$ represents a weighting for the change in emissions ( $y$ axis) and the $\delta^{13} \mathrm{C}$ values of those emissions $(x$ axis) by individual sources. Our addition is to separately consider shale-gas emissions, recognizing that methane emissions from shale gas are more depleted in ${ }^{13} \mathrm{C}$ than for conventional natural gas or other fossil fuels as considered by Worden et al. (2017). For this analysis, we accept that net total emissions have increased by $24.7 \mathrm{Tg}$ per year $( \pm 14.0 \mathrm{Tg}$ per year) since 2007 , driven by an increase of $\sim 28.4 \mathrm{Tg}$ per year for the sum of biogenic emissions and emissions from fossil fuels and a decrease of $\sim 3.7 \mathrm{Tg}$ per year for emissions from biomass burning (Worden et al., 2017).

We start with Eq. (1), which expresses the findings of Worden et al. (2017):

$\mathrm{B}_{\mathrm{W}}+\mathrm{FF}_{\mathrm{W}}=28.4 \mathrm{Tg} \mathrm{yr}^{-1}$,

where $\mathrm{B}_{\mathrm{W}}$ and $\mathrm{FF}_{\mathrm{W}}$ are the estimates from Worden et al. (2017) for the increase respectively in biogenic emissions and fossil-fuel emissions of methane globally since 2007. Equation (2) explicitly considers methane emissions from shale gas:

$\mathrm{B}_{\mathrm{N}}+\mathrm{FF}_{\mathrm{N}}+\mathrm{SG}=28.4 \mathrm{Tg} \mathrm{yr}^{-1}$, 


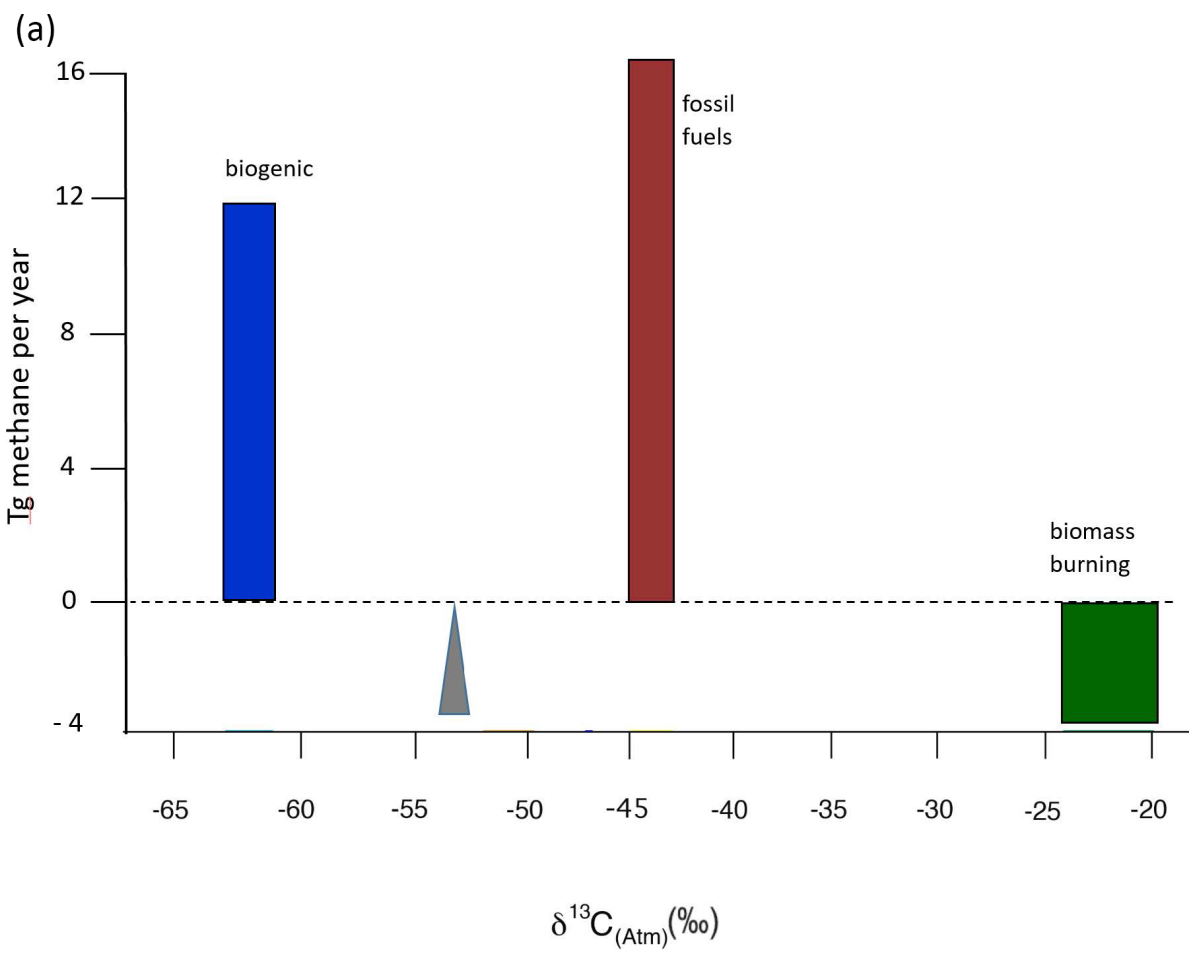

(b)

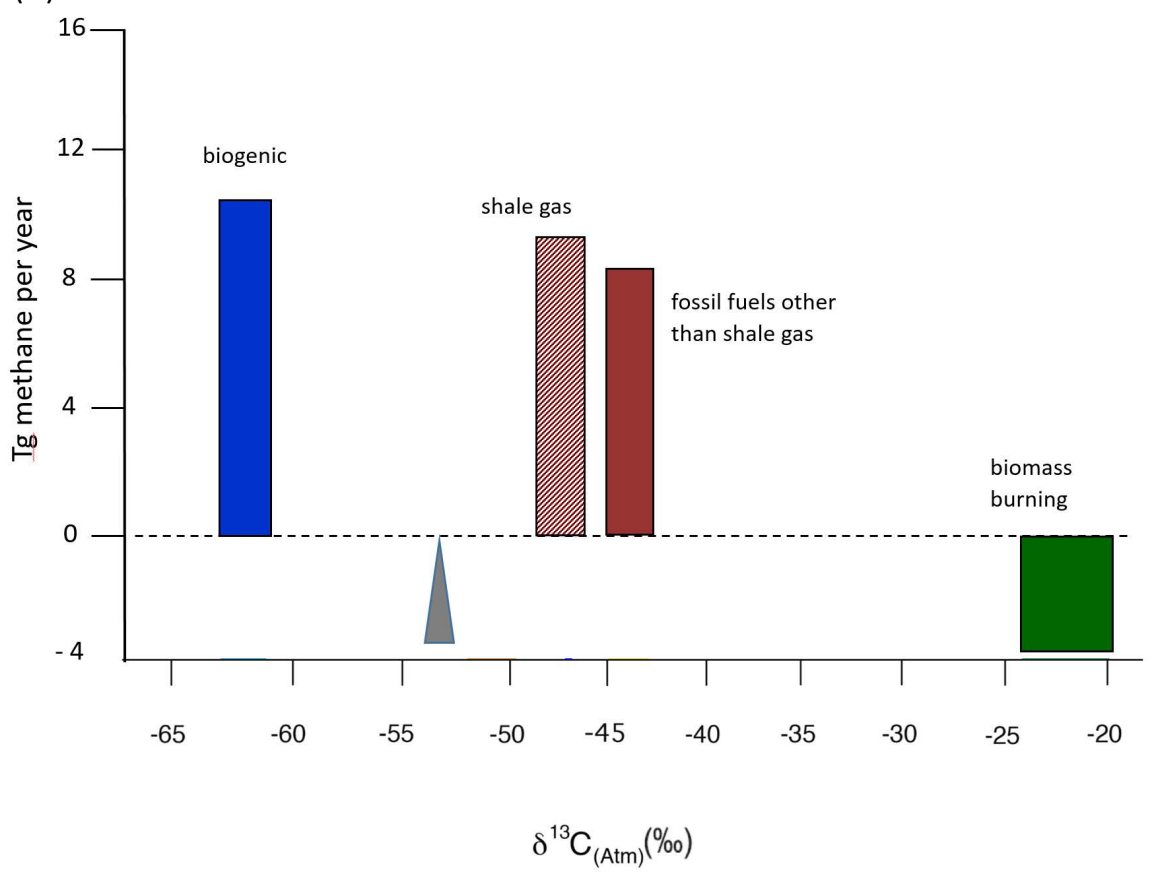

Figure 3. (a) On the $x$ axis, $\delta^{13} \mathrm{C}$ values for methane from biogenic sources, fossil fuel, and biomass burning as presented in Worden et al. (2017) for values from Schwietzke et al. (2016); width of horizontal bars represents the $95 \%$ confidence limits for these values. Triangle indicates the flux-weighted mean input of methane to the atmosphere. The $y$ axis shows mean estimates from Worden et al. (2017) for the increase and decrease in methane emissions from particular sources since 2007 as calculated using the ${ }^{13} \mathrm{C}$ values of Schwietzke et al. (2016). (b) On the $x$ axis, $\delta^{13} \mathrm{C}$ values as in Fig. 3a, except the value for fossil fuels does not include shale gas and a separate estimate for shale-gas value is included (see text). The $y$ axis indicates estimates developed in this paper for the increase or decrease in methane emissions since 2008. 
where $\mathrm{B}_{\mathrm{N}}$ is our new estimate for the increase in the biogenic fluxes since $2007, \mathrm{FF}_{\mathrm{N}}$ is our new estimate for the increase in fossil-fuel emissions other than shale gas since 2007, and SG is our estimate for emissions from shale gas since 2007. Subtracting Eq. (2) from Eq. (1),

$$
\left(\mathrm{B}_{\mathrm{W}}-\mathrm{B}_{\mathrm{N}}\right)+\left(\mathrm{FF}_{\mathrm{W}}-\mathrm{FF}_{\mathrm{N}}\right)-\mathrm{SG}=0 .
$$

Equation (4) builds on Eq. (3) and reweights the information in Fig. 3a for the difference between most fossil fuels and shale gas, multiplying global mass fluxes for each source by the difference between the $\delta^{13} \mathrm{C}$ ratio of each source and the flux-weighted mean for all sources:

$$
\begin{aligned}
& {\left[\left(\mathrm{B}_{\mathrm{W}}-\mathrm{B}_{\mathrm{N}}\right) \cdot \mathrm{D}_{\mathrm{B}-\mathrm{A}}\right]+\left[\left(\mathrm{FF}_{\mathrm{W}}-\mathrm{FF}_{\mathrm{N}}\right) \cdot \mathrm{D}_{\mathrm{FF}-\mathrm{A}}\right]} \\
& \quad-\left(\mathrm{SG} \cdot \mathrm{D}_{\mathrm{SG}-\mathrm{A}}\right)=0,
\end{aligned}
$$

where $\mathrm{D}_{\mathrm{B}-\mathrm{A}}, \mathrm{D}_{\mathrm{FF}-\mathrm{A}}$, and $\mathrm{D}_{\mathrm{SG}-\mathrm{A}}$ are the differences in the $\delta^{13} \mathrm{C}$ ratio of biogenic emissions, fossil fuels, and shale gas compared to the flux-weighted mean $\delta^{13} \mathrm{C}$ ratio for all sources (A). The $x$ axis of Fig. 3b shows the $\delta^{13} \mathrm{C}$ for each source; note that the $y$ axis is the estimate of the change in emissions for each of the sources that we derive below. Next, we multiply both sides of Eq. (3) by $\mathrm{D}_{\mathrm{B}-\mathrm{A}}$,

$$
\begin{aligned}
& {\left[\left(\mathrm{B}_{\mathrm{W}}-\mathrm{B}_{\mathrm{N}}\right) \cdot\left(\mathrm{D}_{\mathrm{B}-\mathrm{A}}\right)\right]+\left[\left(\mathrm{FF}_{\mathrm{W}}-\mathrm{FF}_{\mathrm{N}}\right) \cdot \mathrm{D}_{\mathrm{B}-\mathrm{A}}\right]} \\
& -\mathrm{SG} \cdot\left(\mathrm{D}_{\mathrm{B}-\mathrm{A}}\right)=0 .
\end{aligned}
$$

Subtracting Eq. (5) from Eq. (4),

$$
\begin{gathered}
{\left[\left(\mathrm{FF}_{\mathrm{W}}-\mathrm{FF}_{\mathrm{N}}\right) \cdot\left(\mathrm{D}_{\mathrm{FF}-\mathrm{A}}-\mathrm{D}_{\mathrm{B}-\mathrm{A}}\right)\right]} \\
-\left[\mathrm{SG} \cdot\left(\mathrm{D}_{\mathrm{SG}-\mathrm{A}}-\mathrm{D}_{\mathrm{B}-\mathrm{A}}\right)\right]=0 .
\end{gathered}
$$

Rearranging Eq. (6) to solve for SG,

$$
\begin{aligned}
& \mathrm{SG}=\left(\mathrm{FF}_{\mathrm{W}}-\mathrm{FF}_{\mathrm{N}}\right) \cdot\left(\mathrm{D}_{\mathrm{FF}-\mathrm{A}}-\mathrm{D}_{\mathrm{B}-\mathrm{A}}\right) / \\
& \left(\mathrm{D}_{\mathrm{SG}-\mathrm{A}}-\mathrm{D}_{\mathrm{B}-\mathrm{A}}\right) .
\end{aligned}
$$

Note that from Worden et al. (2017), $\mathrm{FF}_{\mathrm{W}}$ is $16.4 \mathrm{Tg}$ per year.

Although our expectation is that the methane in shale gas is depleted in ${ }^{13} \mathrm{C}$ relative to conventional natural gas, the $\delta^{13} \mathrm{C}$ ratios for the methane in both conventional gas reservoirs and in shale gas vary substantially, changing with the maturity of the gas and several other factors (Golding et al., 2013; Hao and Zou, 2013; Tilley and Muehlenbachs, 2013). The large data set of Sherwood et al. (2017) suggests no systematic difference between the average ratio for shale gas and the average for conventional gas. However, some of the data listed as shale gas in that data set are actually for methane that has migrated from shale to reservoirs (Tilley et al., 2011) and therefore may have been partially oxidized and fractionated (Hao and Zou, 2013). In other cases, the data appear to come both from conventional vertical wells and shalegas horizontal wells in the same region, making interpretation ambiguous (Rodriguez and Philp, 2010; Zumberge et al., 2012). Note that in the Barnett shale region, Texas, the $\delta^{13} \mathrm{C}$ ratio for methane emitted to the atmosphere $(-46.5 \%$; Townsend-Small et al., 2015) is more depleted than the average for wells reported in the Sherwood et al. (2017) data set: $-44.8 \%$ for "group 2A and 2B" wells and $-38.5 \%$ for "group 1" wells (Rodriguez and Philp, 2010) and a $-41.1 \%$ o average value (Zumberge et al., 2012). For our analysis, we use the mean of the $\delta^{13} \mathrm{C}$ ratio $(-46.9 \%$ ) from three studies where the methane clearly came from horizontal, highvolume fractured shale wells: $-47.0 \%$ o for Bakken shale, North Dakota (Schoell et al., 2011), $-46.5 \%$ o for Barnett shale, Texas (Townsend-Small et al., 2015), and $-47.3 \%$ o for Utica shale, Ohio (Botner et al., 2018). Note that several studies have reported mean $\delta^{13} \mathrm{C}$ ratios for methane from organic-rich shales that are more depleted in ${ }^{13} \mathrm{C}$ (more negative) than this: -50.7 (Martini et al., 1998) for Antrim shale, Michigan, -53.3 (McIntosh et al., 2002) and -51.1 (Schlegel et al., 2011) for New Albany shale, Illinois, and -49.3 (Osborn and McIntosh, 2010) for a Devonian shale in Ohio. However, these shales are not typical of the major shale plays supporting the huge increase in gas production over the past decade.

The average $\delta^{13} \mathrm{C}$ ratio for methane in the atmosphere (A) in 2005 was $-47.2 \%$ (Schaefer et al., 2016), which reflects a flux-weighted mean input of methane with a $\delta^{13} \mathrm{C}$ ratio of $-53.5 \%$. This flux-weighted mean value is approximately $6.3 \%$ more depleted in ${ }^{13} \mathrm{C}$ because of fractionation during the oxidation of methane in the atmosphere (Schwietzke et al., 2016; Sherwood et al., 2017). In our analysis, we use this flux-weighted mean value of $-53.5 \%$. Therefore, the mean value for $\mathrm{D}_{\mathrm{FF}-\mathrm{A}}$ is $-9.5 \%$, the value for $\mathrm{D}_{\mathrm{B}-\mathrm{A}}$ is $9.0 \%$, and the value for $\mathrm{D}_{\mathrm{SG}-\mathrm{A}}$ is $-6.6 \%$ (Fig. 3b). Substituting these values into Eq. (7), we see that

$\mathrm{SG}=-1.19 \cdot \mathrm{FF}_{\mathrm{N}}+19.4$.

\section{Estimating increased methane fluxes for coal, oil, and natural gas}

Next, we estimate the likely contributions from coal and oil to the increased methane emissions over the past decade. We estimate the increase in methane emissions from coal between 2006 and 2016 to be $1.3 \mathrm{Tg}$ per year, based on the rise in global coal production of $27 \%$, with almost all of this due to surface-mined coal in China (IEA, 2008, 2017) and using a well-accepted emission factor of $870 \mathrm{~g}$ methane per ton of surface-mined coal (Howarth et al., 2011). Methane emissions from surface-mined coal tend to be low, as much of the methane that was once associated with the coal has degassed over geological time. This estimate is very close to the $1.1 \mathrm{Tg}$ per year increase from coal emissions in China between 2009 and 2015 as estimated based on satellite observations (Miller et al., 2019). For oil, global production increased by $9.6 \%$ (IEA, 2008, 2017), thereby increasing methane emissions by approximately $1.6 \mathrm{Tg}$ per year (using emission factors from 
NETL 2008; as detailed in Howarth et al., 2011). Therefore, of the increase in $28.4 \mathrm{Tg}$ per year from fossil fuels plus biogenic sources since 2005 (see discussion above), we estimate $2.9 \mathrm{Tg}$ per year to be from increased emissions from coal and oil, leaving an increase of approximately $25.5 \mathrm{Tg}$ per year from natural gas (including shale gas) plus biogenic sources.

As noted above, shale gas accounted for $63 \%$ of the global increase in all natural gas production between 2005 and 2015 (EIA, 2016; IEA, 2017). If we make the simplifying assumption that for both shale gas and conventional natural gas, emissions are equal as a percentage of the gas produced, then

$\mathrm{SG}=0.63 \cdot \mathrm{TG}$,

and

$\mathrm{CG}=0.37 \cdot \mathrm{TG}$,

where TG is total increase in emissions from all natural gas. Note that we test this assumption later in our sensitivity analyses, since some research indicates that emissions from shale gas are higher than for conventional gas as a percentage of gas production. Rearranging Eq. (9) for TG and substituting into Eq. (10),

$\mathrm{CG}=0.37 \cdot(\mathrm{SG} / 0.63), \quad$ or $\quad \mathrm{CG}=0.59 \cdot \mathrm{SG}$.

$\mathrm{FF}_{\mathrm{N}}$ is the sum of $\mathrm{CG}(0.59 \cdot \mathrm{SG})$ plus the emissions from oil and coal (2.9 Tg per year), or

$\mathrm{FF}_{\mathrm{N}}=(0.59 \cdot \mathrm{SG})+2.9$.

Substituting Eq. (12) into Eq. (8) and solving for SG, we estimate that the increase in shale-gas emissions between 2005 and 2015 was 9.4 Tg per year (Table 1; Fig. 3b). From Eq. (11), increased emissions from conventional natural gas are then estimated to be $5.5 \mathrm{Tg}$ per year, emissions from all natural gas (shale plus conventional) are estimated to be 14.9 Tg per year, and emissions from all fossil fuels (including coal and oil) are estimated to be $17.8 \mathrm{Tg}$ per year. From Eq. (3), increased emissions from biogenic sources are estimated to be $10.6 \mathrm{Tg}$ per year. While the biogenic sources are important, the increase in fossil-fuel emissions has been greater, and shale gas makes up more than half of these increased fossil-fuel emissions.

\section{Comparison with prior estimates}

Our best estimate for the increase in methane emissions from all fossil fuels since 2008 (shale gas, conventional natural gas, coal, and oil) of $17.8 \mathrm{Tg}$ per year is $9 \%$ larger than the mean estimate of Worden et al. (2017) of $16.4 \mathrm{Tg}$ per year (Table 1). Our estimate for the increased emissions from biogenic sources, $10.6 \mathrm{Tg}$ per year, is $12 \%$ lower than the Worden et al. (2017) estimate of $12 \mathrm{Tg}$ per year (Table 1). Thus, our estimates are not greatly different from those of Worden et al. (2017), although our estimate for fossil fuels is larger and our estimate for biogenic fluxes lower than their estimates. On the other hand, comparing emissions for the 2003 2013 period with those from the late 20th century, Schwietzke et al. (2016) concluded that biogenic emissions had risen by $\sim 27 \mathrm{Tg}$ per year, while fossil-fuel emissions had decreased by $\sim 18 \mathrm{Tg}$ per year. And Schaefer et al. (2016) concluded that increased methane emissions since 2006 have been "predominantly biogenic" and that fossil-fuel emissions likely have fallen.

We estimate that shale gas has contributed $33 \%$ of the global increase in all methane emissions in recent years (Table 1). Since virtually all shale-gas development globally through 2015 occurred in North America (mostly in the United States but also western Canada), we conclude that at least $33 \%$ of the increase in methane fluxes came from North America. This is consistent with the work of Turner et al. (2016), who used satellite data to conclude that $30 \%$ to $60 \%$ of the global increase in methane emissions between 2002 and 2014 came from the United States. On the other hand, Nisbet et al. $(2016,2019)$ used monitoring data to infer spatial changes in methane emissions over time and emphasized that much of the increase in recent years originated in the tropics and Southern Hemisphere, although they noted that the northern temperate latitude played a major role in the large increase in emissions in 2014 (Nisbet et al., 2019), a time of major increase in shale-gas development (EIA, 2016). While our estimate for increased emissions from fossil fuels is only marginally greater than that of the Worden et al. (2017) paper upon which we build our analysis, we demonstrate the importance of shale gas as a major part of these increased fossil-fuel emissions and thereby explicitly link the increased emissions to North America.

Our estimate of increased emissions of $9.4 \mathrm{Tg}$ per year from shale-gas development is quite reasonable in light of the growing body of evidence from measurements made at local to regional scales. Between 2005 and 2015, global shale-gas production rose by 404 billion cubic meters per year (Fig. 2b; EIA, 2016). Assuming that $93 \%$ of natural gas is composed of methane (Schneising et al., 2014), our estimate of the increase in methane emissions from shale gas represents $3.5 \%$ of the shale-gas production (270 Tg per year of methane produced from shale-gas operations on average in 2015). This estimate of $3.5 \%$ (based on global change in the ${ }^{13} \mathrm{C}$ content of methane) represents full life-cycle emissions, including those from the gas well site, transportation, processing, storage systems, and final distribution to customers. Our estimate is well within the range reported in several recent studies for shale gas and in fact is at the low end for many (but not all) of these studies (Howarth et al., 2011; Pétron et al., 2014; Karion et al., 2013; Caulton et al., 2014; Schneising et al., 2014; Howarth, 2014). Alvarez et al. (2018) recently presented a summary estimate for natural gas emissions in the United States (both conventional and shale gas) of $2.3 \%$ using bottom-up, facility-based data. However, they noted that 
Table 1. Estimates for sources of increased or decreased methane emissions to the atmosphere in recent years (teragrams per year). All values are positive, except as specified.

\begin{tabular}{lcll}
\hline & This study $^{\mathrm{a}}$ & $\begin{array}{l}\text { Worden et al. }^{\mathrm{b}} \\
(2017)\end{array}$ & $\begin{array}{l}\text { Schwietzke et al. }^{\mathrm{c}} \\
(2016)\end{array}$ \\
\hline All fossil fuels & 17.8 & $\begin{array}{l}16.4 \\
( \pm 3.6)\end{array}$ & Negative $\sim 18$ \\
& & & \\
- Shale gas & 9.4 & & \\
- Conventional gas & 5.5 & & \\
- Oil & 1.6 & & \\
- Coal & 1.3 & & \\
\hline Biogenic sources & 10.6 & 12.0 & 27 \\
& & $( \pm 2.5)$ & \\
\hline
\end{tabular}

\footnotetext{
a Time period is 2008-2014 compared to 2000-2007. ${ }^{\text {b }}$ Time period is 2008-2014 compared to 2000-2007, using the Schwietzke et al. (2016) data set with values from their Fig. 4 and assuming a decrease in biomass burning of $3.7 \mathrm{Tg}$ per year. Uncertainty is as shown in original publication. c Time period is for 2003-2013 compared to 1985-2002, with values from their Fig. 2 b.

Uncertainties are large, and only mean differences shown here.
}

Table 2. Exploration of sensitivity to assumptions for estimates of increase in global methane emissions in recent years (teragrams per year).

\begin{tabular}{|c|c|c|c|}
\hline & Base analysis ${ }^{\mathrm{a}}$ & $\begin{array}{l}\text { Increased emission factor } \\
\text { for shale gas } \\
(\text { sensitivity test no. } 1)^{b}\end{array}$ & $\begin{array}{l}\text { Explicit consideration } \\
\text { of shale oil } \\
(\text { sensitivity test no. } 2)^{\mathrm{C}}\end{array}$ \\
\hline All fossil fuels & 17.8 & 18.0 & 18.2 \\
\hline - All natural gas & 14.9 & 15.1 & 12.0 \\
\hline - Shale gas & 9.4 & 10.8 & 7.8 \\
\hline - Conventional gas & 5.5 & 4.3 & 4.2 \\
\hline - All oil & 1.6 & 1.6 & 4.9 \\
\hline - Shale oil & & & 4.2 \\
\hline - Conventional oil & & & 0.7 \\
\hline - Coal & 1.3 & 1.3 & 1.3 \\
\hline Biogenic sources & 10.6 & 10.4 & 10.2 \\
\hline
\end{tabular}

top-down estimates from approaches such as airplane flyovers give higher values than the bottom-up estimates they emphasized. In fact, a careful comparison of bottom-up and top-down approaches for one shale-gas field showed $45 \%$ higher emissions from the top-down approach due to undersampling of some emission events by the bottom-up, facilitybased approach (Vaughn et al., 2018). Further, Alvarez et al. (2018) used a very low value for the methane emissions from local distribution pipelines, only $0.08 \%$ (see discussion in Howarth et al., 2011). Many studies suggest that distribution emissions in Boston, Los Angeles, Indianapolis, and Texas cities may be as high as $2.5 \%$ or more, not $0.08 \%$ (Howarth et al., 2011; McKain et al., 2015; Lamb et al., 2016; Wunch et al., 2016), so a full life cycle of $3.5 \%$ emissions from shale gas over the past decade is quite plausible and perhaps even low.

\section{Sensitivity analyses}

Our analysis contains two major assumptions: (1) that methane emissions as a percentage of gas produced are the same for shale gas and conventional natural gas (Eqs. 9 and 10); and (2) that emissions from oil have remained proportional to the global rate of oil production. Here we explore the sensitivity of our analysis to these assumptions. With regard to the first assumption, some evidence suggests that percent emissions may be higher from shale gas than from conventional natural gas, perhaps due to venting at the time of flowback following high-volume hydraulic fracturing of 
(a)

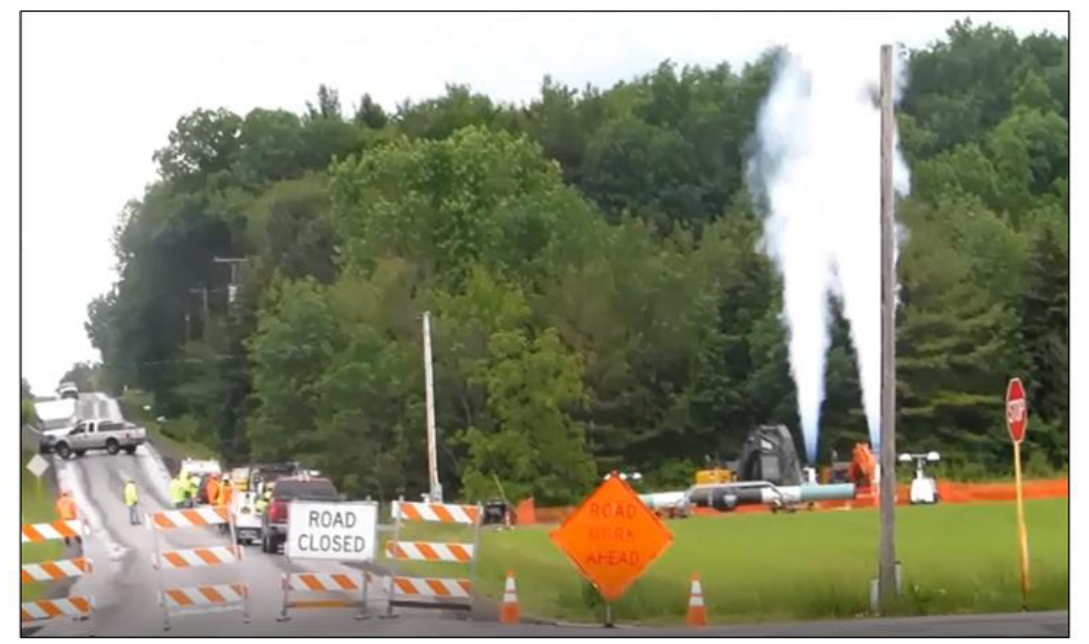

(b)

(c)

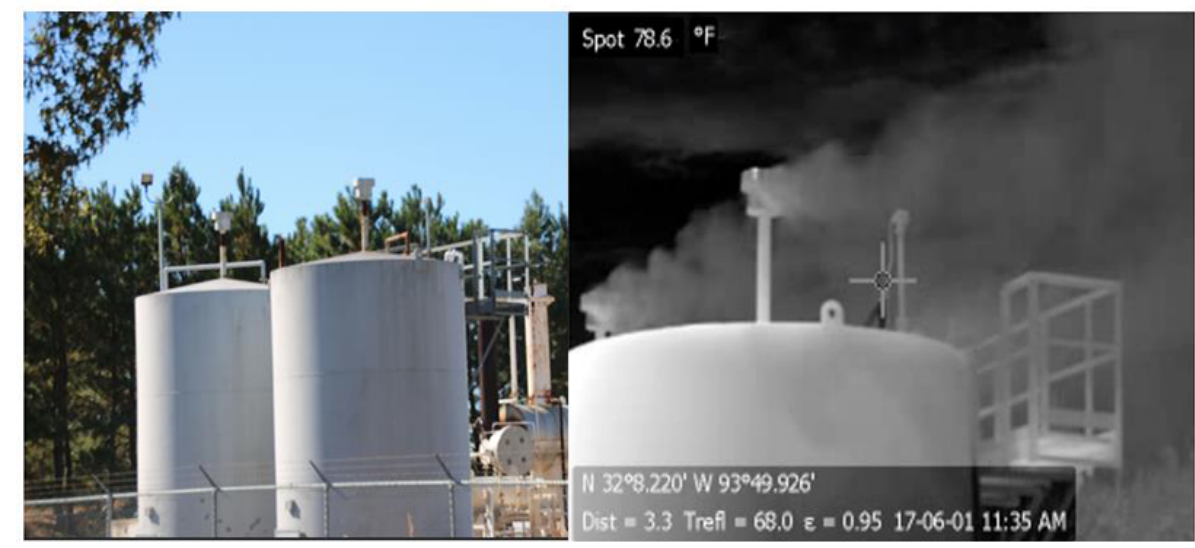

Figure 4. (a) Gas blowdown for maintenance on a pipeline in Yates County, New York. While methane is invisible, the cooling caused by the blowdown condenses water vapor, leading to the obvious cloud. Photo courtesy of Jack Ossont. (b, c) Gas storage tanks receiving natural gas from feeder pipelines before compression for transport in high-pressure pipelines at the Haynseville shale formation, Texas. Photo on left was taken with a normal camera. Photo on the right was taken with a forward-looking infrared (FLIR) camera tuned to the infrared spectrum of methane, allowing visualization of methane, which is invisible in the normal camera view and to the naked eye. Photo courtesy of Sharon Wilson.

shale-gas wells (Howarth et al., 2011) and also due to release of methane from trapped pockets when drilling down through a very long legacy (often a century or more) of prior fossilfuel operations (coal, oil, and gas) to reach the deeper shale formations (Caulton et al., 2014; Howarth, 2014). For this first sensitivity analysis, we modify equations Eq. (9) through Eq. (12) with new equations Eq. (A1) through Eq. (A4) to reflect a $50 \%$ higher emission factor for shale gas than for conventional gas, as proposed in Howarth et al. (2011; see Appendix A). With this change in assumptions, estimated shale-gas emissions increase by $12 \%$ (10.8 instead of $9.4 \mathrm{Tg}$ per year), which corresponds to a life-cycle emission factor of $4.0 \%$ rather than $3.5 \%$. Biogenic emissions remain virtually unchanged (10.4 instead of $10.6 \mathrm{Tg}$ per year), as do total fossil-fuel emissions (18 instead of $17.8 \mathrm{Tg}$ per year; Table 2).

Our second major assumption in the base analysis is that methane emission factors for oil production have remained constant over time as a function of production. This may not be true, since $60 \%$ of the increase in global oil production between 2005 and 2015 was due to tight oil production from shales using the same technologies that allowed shale-gas development, high-precision directional drilling and high-volume hydraulic fracturing (calculated from data in EIA, 2015, 2018). Large quantities of methane are often co-produced with this tight shale oil, and because oil is a much more valuable product than natural gas, for shale-oil fields removed from easy access to natural gas markets, much 
of the methane may be vented or flared rather than delivered to the market. This may be part of the reason for the large increase in methane emissions between 2008 and 2011 in the Bakken shale fields of North Dakota (Schneising et al., 2014).

For sensitivity scenario no. 2, we modify Eq. (9) through Eq. (12) with new Eq. (B1) through Eq. (B4) to allow for higher emissions associated with shale oil than from conventional oil production (see Appendix B). For this, we follow the approach of Schneising et al. (2014) in combining shale gas and shale oil, scaling the increase in production since 2005 by the energy value of the two products. As in our baseline analysis developed in equations Eq. (1) through Eq. (12), we assume that conventional natural gas and shale gas have the same percentage methane emission per unit of produced gas. Here we further assume that shale oil has the same emission rate as well, scaled to the energy content of oil compared to natural gas. This sensitivity analysis again has very little influence on either total emissions from fossil fuels (18.2 instead of $17.8 \mathrm{Tg}$ per year) or biogenic emissions (10.2 instead of $10.6 \mathrm{Tg}$ per year; Table 2). The contribution from shale gas falls somewhat (from 9.4 to $7.8 \mathrm{Tg}$ per year), as does that from conventional natural gas (from 5.5 to $4.2 \mathrm{Tg}$ per year), while shale oil becomes an important emission source (4.2 Tg per year). Overall in this scenario, increased emissions from fossil fuels extracted from shales (gas plus oil) are $12 \mathrm{Tg}$ per year, two-thirds of the total increase due to fossil fuels.

\section{Conclusions}

We conclude that increased methane emissions from fossil fuels likely exceed those from biogenic sources over the past decade (since 2007). The increase in emissions from shale gas (perhaps in combination with those from shale oil) makes up more than half of the total increased fossil-fuel emissions. That is, the commercialization of shale gas and oil in the 21 st century has dramatically increased global methane emissions.

Note that while methane emissions are often referred to as "leaks", some of the emissions include purposeful venting, including the release of gas during the flowback period immediately following hydraulic fracturing, the rapid release of gas from blowdowns during emergencies but also for routine maintenance on pipelines and compressor stations (Fig. 4a), and the steadier but more subtle release of gas from storage tanks (Fig. 4b) and compressor stations to safely maintain pressures (Howarth et al., 2011). This suggests large opportunities for reducing emissions, but at what cost? Do large capital investments for rebuilding natural gas infrastructure make economic sense, or would it be better to move towards phasing natural gas out as an energy source and instead invest in a 21 st-century energy infrastructure that embraces renew- able energy and much more efficient heat and transportation through electrification (Jacobson et al., 2013)?

In October 2018, the Intergovernmental Panel on Climate Change issued a special report, responding to the call of the United Nations COP21 negotiations to keep the planet well below $2{ }^{\circ} \mathrm{C}$ of the pre-industrial baseline (IPCC, 2018). They noted the need to reduce both carbon dioxide and methane emissions, and they recognized that the climate system responds more quickly to methane: reducing methane emissions offers one of the best routes for immediately slowing the rate of global warming (Shindell et al., 2012). Given our finding that natural gas (both shale gas and conventional gas) is responsible for much of the recent increases in methane emissions, we suggest that the best strategy is to move as quickly as possible away from natural gas, reducing both carbon dioxide and methane emissions. Natural gas is not a bridge fuel (Howarth, 2014).

Finally, in addition to contributing to climate change, methane emissions lead to increased ground-level ozone levels, with significant damage to public health and agriculture. Based on the social cost of methane emissions of USD 2700 to USD 6000 per ton (Shindell, 2015), our baseline estimate for increased emissions from shale gas of $9.4 \mathrm{Tg}$ per year corresponds to damage to public health, agriculture, and the climate of USD 25 billion to USD 55 billion per year for each of the past several years. This is comparable to the wholesale value for this shale gas over these years.

Data availability. No data sets were used in this article. 
Appendix A: Sensitivity case no. 1: emissions per unit of gas produced assumed to be $50 \%$ greater for shale gas than for conventional gas

First we modify Eqs. (9) and (10) as follows to reflect that methane emissions per unit of gas produced are $50 \%$ greater for shale gas than for conventional natural gas:

$\mathrm{SG}=1.2 \cdot(0.63 \cdot \mathrm{TG}), \quad$ or $\quad \mathrm{SG}=0.76 \cdot \mathrm{TG}$,

and

$\mathrm{CG}=0.8 \cdot(0.37 \cdot \mathrm{TG}), \quad$ or $\quad \mathrm{CG}=0.30 \cdot \mathrm{TG}$.

Rearranging Eq. (A1) for $\mathrm{TG}$ and substituting into Eq. (A2),

$\mathrm{CG}=0.30 \cdot(\mathrm{SG} / 0.76), \quad$ or $\quad \mathrm{CG}=0.40 \cdot \mathrm{SG}$.

Since $\mathrm{FF}_{\mathrm{N}}$ is the sum of $\mathrm{CG}$ and the $2.9 \mathrm{Tg}$ per year emissions for oil and coal,

$\mathrm{FF}_{\mathrm{N}}=0.40 \cdot \mathrm{SG}+2.9$.

Substituting Eq. (A4) into Eq. (8) and solving for SG, we estimate that the increase in shale-gas emissions between 2005 and 2015 was $10.8 \mathrm{Tg}$ per year (Table 2). From Eq. (A3), for conventional natural gas, $\mathrm{CG}=4.3 \mathrm{Tg}$ per year. The increase in total fossil-fuel emissions are estimated to be the contributions from coal ( $1.3 \mathrm{Tg}$ per year) and oil (1.6 Tg per year) plus $\mathrm{SG}$ and $\mathrm{CG}$, or $18 \mathrm{Tg}$ per year. From Eq. (3), biogenic emissions are estimated to have increased by $10.4 \mathrm{Tg}$ per year. These values are reported in Table 2 .

\section{Appendix B: Sensitivity case no. 2: explicit consideration of shale oil (tight oil)}

For the base analysis presented in the main text using equations Eq. (1) through Eq. (12), we assumed that increased emissions from the additional oil development over the past decade were proportional to the increase in that rate of development. That is, the oil produced in recent years had the same emission factor as that for oil produced a decade or more ago. However, $60 \%$ of the increase in oil production globally between 2005 and 2015 was for tight oil from shale formations (calculated from data in EIA, 2015, 2018), and methane emissions from this shale oil may be greater than for conventional oil. In sensitivity case no. 2, we consider increased emissions from conventional oil and from tight shale oil separately. For conventional oil, the increase in emissions is $40 \%$ of the total oil emissions from the base analysis $(40 \%$ of $1.6 \mathrm{Tg}$ per year, or $0.65 \mathrm{Tg}$ per year, rounded to 0.7 in Table 2), reflecting that conventional oil contributed $40 \%$ to the growth in oil production between 2005 and 2015.

For the tight shale oil, we follow the approach used by Schneising et al. (2014): the increases in methane emissions from shale gas and shale oil are considered together, normalized to the energy content of the two fuels. Shale-gas production increased by 405 billion cubic meters per year between 2005 and 2015 (EIA, 2016). With an energy content of 37 MJ per cubic meter, this reflects an increase in 15.9 trillion MJ per year. For shale oil, production increased by 230 liters per year between 2005 and 2015 (EIA, 2015, 2018). With an energy content of $38 \mathrm{MJ}$ per liter, this reflects an increase in 8.9 trillion MJ per year. Conventional natural gas production increased by 238 billion cubic meters per year between 2005 and 2015 (EIA, 2016). With an energy content of $37 \mathrm{MJ} \mathrm{m}^{-3}$, this reflects an increase in 8.8 trillion $\mathrm{MJ}$ per year. Therefore, the sum of the increase in production for shale gas, shale oil, and conventional natural gas is 33.6 trillion megajoules per year. Shale gas represents $48 \%$ of this, shale oil represents $26 \%$, and conventional natural gas represents $26 \%$. The sum of shale gas and shale oil represents $74 \%$ of the total.

For this sensitivity analysis, we further assume that shale gas and conventional natural gas have the same percentage emissions, as in our base case analysis in the main text, and that the ${ }^{13} \mathrm{C}$ content of methane from shale oil is the same as for shale gas. Using these assumptions, we modify Eqs. (9) and (10) as follows:

$\mathrm{SG} \& \mathrm{O}=0.74 \cdot \mathrm{TG} \& \mathrm{SO}$,

and

$\mathrm{CG}=0.26 \cdot \mathrm{TG} \& \mathrm{SO}$,

where SG\&O is shale gas plus shale oil and TG\&SO is total natural gas plus shale oil. Rearranging Eq. (B1) for TG\&SO and substituting into Eq. (B2),

$\mathrm{CG}=0.26 \cdot(\mathrm{SG} \& \mathrm{O} / 0.74), \quad$ or $\quad \mathrm{CG}=0.35 \cdot \mathrm{SG} \& \mathrm{O}$.

Since $\mathrm{FF}_{\mathrm{N}}$ is the sum of $\mathrm{CG}$ and the $2.0 \mathrm{Tg}$ per year emissions for coal and conventional oil,

$\mathrm{FF}_{\mathrm{N}}=0.35 \cdot \mathrm{SG}+2.0$.

Substituting Eq. (B4) into Eq. (8) and solving for SG, we estimate that the increase in methane emissions from shale oil plus shale gas between 2005 and 2015 was 12 Tg per year. From Eq. (B3), increased emissions from conventional natural gas are $4.2 \mathrm{Tg}$ per year (Table 2).

The total increase in fossil-fuel emissions is estimated to be the contributions from coal (1.3 Tg per year), conventional oil $(0.7 \mathrm{Tg}$ per year), and conventional natural gas $(4.2 \mathrm{Tg}$ per year) plus the sum for shale gas plus shale oil (12 Tg per year), or $18.2 \mathrm{Tg}$ per year. We can separately estimate shale gas and shale oil, estimating the proportion of the sum of the two made up by shale gas as follows:

$$
\begin{aligned}
& 15.9 \text { trillion } \mathrm{MJ} \mathrm{yr}^{-1} / \\
& \left(15.9 \text { trillion } \mathrm{MJ} \mathrm{yr}^{-1}\right. \\
& \left.+8.9 \mathrm{MJ} \mathrm{yr}^{-1}\right)=0.64
\end{aligned}
$$


Therefore, of the increased emissions of $12 \mathrm{Tg}$ per year for $\mathrm{SG} \& \mathrm{O}$, the increase for shale-gas emissions is $7.8 \mathrm{Tg}$ per year and that for shale-oil emissions is $4.2 \mathrm{Tg}$ per year. These values are reported in Table 2. 
Competing interests. The authors declare that they have no conflict of interest.

Acknowledgements. We thank Tony Ingraffea, Amy TownsendSmall, Alexander Turner, Euan Nisbet, Martin Manning, Dennis Swaney, Roxanne Marino, three anonymous reviewers, and associate editor Jack Middelburg for comments on earlier versions of this paper. We particularly thank Dennis Swaney for help with the analyses we report. We thank Gretchen Halpert for the artwork in Figs. 1 and 2, Sharon Wilson for the photographs in Fig. 4b, c, and Jack Ossont for the photograph in Fig. 4a. Tony Ingraffea helped interpret these photographs.

Financial support. This research has been supported by the Park Foundation (grant no. 16-612) and an endowment given by David R. Atkinons to support the professorship at Cornell University held by Robert W. Howarth.

Review statement. This paper was edited by Jack Middelburg and reviewed by three anonymous referees.

\section{References}

Alvarez, R. A., Zavalao-Araiza, D., Lyon, D. R., Allen, D. T., Barkley, Z. R., Brandt, A. R., Davis, K. J., Herndon, S. C., Jacob, D. J., Karion, A., Korts, E. A., Lamb, B. K., Lauvaux, T., Maasakkers, J. D., Marchese, A. J., Omara, M., Pacala, J. W., Peiachl, J., Robinson, A. J., Shepson, P. B., Sweeney, C., Townsend-Small, A., Wofsy, S. C., and Hamburg, S. P.: Assessment of methane emissions from the U.S. oil and gas supply chain, Science, 361, 186-188, https://doi.org/10.1126/science.aar7204, 2018.

Baldassare, F. J., McCaffrey, M. A., and Harper, J. A.: A geochemical context for stray gas investigations in the northern Appalachian Basin: Implications of analyses of natural gases from Neogene-through Devonian-age strata, AAPG Bull., 98, 341372, https://doi.org/10.1306/06111312178, 2014.

Botner, E. C., Townsend-Small, A., Nash, D. B., Xu, X., Schimmelmann, A., and Miller, J. H.: Monitoring concentration and isotopic composition of methane in groundwater in the Utica Shale hydraulic fracturing region of Ohio, Environ. Monit. Assess., 190, 322-337, https://doi.org/10.1007/s10661-018-6696-1, 2018.

Burruss, R. C. and Laughrey, C. D.: Carbon and hydrogen isotopic reversals in deep basin gas: evidence for limits to the stability of hydrocarbons, Org. Geochem., 41, 1285-1296, https://doi.org/10.1016/j.orggeochem.2010.09.008, 2010.

Caulton, D. R., Shepson, P. D., Santoro, R. L., Sparks, J. P., Howarth, R. W., Ingraffea, A., Camaliza, M. O., Sweeney, C., Karion, A., Davis, K. J., Stirm, B. H., Montzka, S. A., and Miller, B.: Toward a better understanding and quantification of methane emissions from shale gas development, P. Natl. Acad. Sci. USA, 111, 6237-6242, https://doi.org/10.1073/pnas.1316546111, 2014.
EIA: Shale gas and tight oil and commercially produced in just four countries, Energy Information Administration, US Department of Energy, available at: https:/www.eia.gov/todayinenergy/ detail.php?id=19991 (last access: 14 September 2018), 2015.

EIA: Shale gas production drives world natural gas production growth, Energy Information Administration, US Department of Energy, available at: https://www.eia.gov/todayinenergy/detail. php?id=27512 (last access: 12 September 2018), 2016.

EIA: Table 1.2, World crude oil production 1960-2017, Monthly energy review, June 2018, Energy Information Administration, US Department of Energy, 1-244, 2018.

Golding, S. D., Boreham, C. J., and Esterle, J. S.: Stable isotope geochemistry of coal bed and shale gas and related production waters: A review, Int. J. Coal Geolog., 120, 24-40, https://doi.org/10.1016/j.coal.2013.09.001, 2013.

Hao, F. and Zou, H.: Cause of shale gas geochemical anomalies and mechanisms for gas enrichment and depletion in high-maturity shales, Mar. Petrol. Geol., 44, 1-12, https://doi.org/10.1016/j.marpetgeo.2013.03.005, 2013.

Howarth, R. W.: A bridge to nowhere: Methane emissions and the greenhouse gas footprint of natural gas, Energy Sci. Eng., 2, 4760, https://doi.org/10.1002/ese3.35, 2014.

Howarth, R. W., Santoro, R., and Ingraffea, A.: Methane and the greenhouse gas footprint of natural gas from shale formations, Clim. Change Lett., 106, 679-690, https://doi.org/10.1007/s10584-011-0061-5, 2011.

IEA: World Energy Outlook, International Energy Agency, available at: https://webstore.iea.org/world-energy-outlook-2008 (last access: 12 September 2018), 2008.

IEA: Key World Energy Statistics, International Energy Agency, available at: https://www.iea.org/publications/freepublications/ publication/KeyWorld2017.pdf (last access: 12 September 2018), 2017.

IPCC: Climate Change 2013: The Physical Science Basis. Contribution of Working Group I to the Fifth Assessment Report of the Intergovernmental Panel on Climate Change, Intergovernmental Panel on Climate Change, chap. 8, 659-740, 2013.

IPCC: Summary for Policymakers, in: Global warming of $1.5^{\circ} \mathrm{C}$. An IPCC Special Report on the impacts of global warming of $1.5^{\circ} \mathrm{C}$ above pre-industrial levels and related global greenhouse gas emission pathways, in the context of strengthening the global response to the threat of climate change, sustainable development, and efforts to eradicate poverty, Intergovernmental Panel on Climate Change, available at: http://www.ipcc.ch/report/sr15/ (last access: 29 March 2019), 2018.

Jacobson, M. Z., Howarth, R. W., Delucchi, M. A., Scobies, S. R., Barth, J. M., Dvorak, M. J., Klevze, M., Katkhuda, H., Miranda, B., Chowdhury, N. A., Jones, R., Plano, L., and Ingraffea, A. R.: Examining the feasibility of converting New York State's all-purpose energy infrastructure to one using wind, water, and sunlight, Energ. Policy, 57, 585-601, https://doi.org/10.1016/j.enpol.2013.02.036, 2013.

Karion, A., Sweeney, C., Pétron, G., Frost, G., Hardesty, R. M., Kofler, J., Miller, B. R., Newberger, T., Wolter, S., Banta, R., and Brewer, A.: Methane emissions estimate from airborne measurements over a western United States natural gas field, Geophys. Res. Lett., 40, 4393-4397, https://doi.org/10.1002/grl.50811, 2013. 
Lamb, B. K., Cambaliza, M. O. L., Davis, K. J., Edburg, S. L., Ferrara, T. W., Floerchinger, C., Heimburger, A. M. F., Herndon, S., Lauvaux, T., Lavoie, T., Lyon, D. R., Miles, N., Prasad, K. R., Richardson, S., Roscioli, J. R., Salmon, O. E. Shepson, P. B., Stirm, B. H., and Whetstone, J.: Direct and indirect measurements and modeling of methane emissions in Indianapolis, Indiana, Environ. Sci. Technol., 50, 8910-8917, https://doi.org/10.1021/acs.est.6b01198, 2016.

Martini, A. M., Walter, L. M., Budai, J. M., Ku, T. C. W., Kaiser, C. J., and Schoell, M.: Genetic and temporal relations between formation waters and biogenic methane: Upper Devonian Antrim Shale, Michigan Basin, USA, Geochim. Cosmochim. Ac., 62, 1699-1720, 1998.

McIntosh, J. C., Walter, L. M., and Martini, A. M.: Pleistocene recharge to mid-continent basins: effects on salinity structure and microbial gas generation, Geochim. Cosmochim. Ac., 66, 16811700, https://doi.org/10.1016/S0016-7037(01)00885-7, 2002.

McKain, K., Down, A., Raciti, S. M., Budney, J., Hutyra, L. R., Floerchinger, C., Herndon, S. C., Nehrkorn, T., Zahniser, M. S., Jackson, R. B., Phillips, N., and Wofsy, S. C.: Methane emissions from natural gas infrastructure and use in the urban region of Boston, Massachusetts, P. Natl. Acad. Sci. USA, 112, 19411946, https://doi.org/10.1073/pnas.1416261112, 2015.

Miller, S. M., Michalak, A. M., Detmers, R. R., Hasekamp, O. P., Bruhwiler, L. M. P., and Schwietezke, S.: China's coal mine methane regulations have not curbed growing emissions, Nat. Commun., 10, 1-8, https://doi.org/10.1038/s41558-019-0432-x, 2019.

Nisbet, E. G., Dlugokencky, E. J., Manning, M. R., Lowry, D., Fisher, R. E., France, J. L., Michel, S. E., Miller, J. B., White, J. W. C., Vaughn, B., Bousquet, P., Pyle, J. A., Warwick, N. J., Cain, M., Brownlow, R., Zazzeri, G., Lanoiselle, M., Manning, A. C. Gloor, E., Worthy, D. E. J., Brunke, E. G., Labuschagne, C., Wolff, E. W., and Ganesan, A. L.: Rising atmospheric methane: 2007-2014 growth and isotopic shift, Global Biogeochem. Cy., 30, 1356-1370, https://doi.org/10.1002/2016GB005406, 2016.

Nisbet, E. G., Manning, M. R., Dlugokencky, E. J., Fisher, R. E., Lowry, D., Michel, S. E., Myhre, C. L., Platt, S. M., Allen, G., Bousquet, P., Brownlow, R., Cain, M., France, J. L., Hermansen, O., Hossaini, R., Jones, A. E, Levin, I., Manning, A. C., Myhre, G., Pyle, J. A., Vaughn, B. H., Warwich, N. J., and White, J. W. C.: Very strong atmospheric methane growth in the 4 years 2014 2017: Implications for the Paris Agreement, Global Biogeochem. Cy., 33, 318-342, https://doi.org/10.1029/2018GB006009, 2019.

Osborn, S. G. and McIntosh, J. C.: Chemical and isotopic tracers of the contribution of microbial gas in Devonian organic-rich shales and reservoir sandstones, northern Appalachian Basin, Appl. Geochem., 25, 456-471, https://doi.org/10.1016/j.apgeochem.2010.01.001, 2010.

Pétron, G., Karion, A., Sweeney, C., Miller, B., Montzka, S. A., Frost, G.J., Trainer, M., Tans, P., Andrews, A., Kofler, J., Helming, D., Guenther, D., Dlugokencky, E., Lang, P., Newberger, T., Wolter, S., Hall, B., Novelli, P., Brewer, R., Conley, S., Hardesty, M., Banta, R., White, A., Noone, D., Wolfe, D., and Schnell, R.: A new look at methane and nonmethane hydrocarbon emissions from oil and natural gas operations in the Colorado Denver-Julesburg Basin, J. Geophys. Res.-Atmos., 119, 6836-6852, https://doi.org/10.1002/2013JD021272, 2014.
Rice, A. L., Butenhoff, C. L., Tema, D. G., Florian, H. R., Khalil, M. A. K., and Rasmussen, R. A.: Atmospheric methane isotopic record favors fossil sources flat in 1980s and 1990s with recent increase, P. Natl. Acad. Sci. USA, 13, 10791-10796, https://doi.org/10.1073/pnas.1522923113, 2016.

Rodriguez, N. D. and Philp, R. P.: Geochemical characterization of gases from the Mississippian Barnett shale, Fort Worth Basin, Texas, AAPG Bull., 94, 1641-56, https://doi.org/10.1306/04061009119, 2010.

Rooze, J., Egger, M., Tsandev, I., and Slomp, C. P.: Iron-dependent anaerobic oxidation of methane in coastal surface sediments: Potential controls and impact, Limnol. Oceanogr., 61, S267-S282, https://doi.org/10.1002/lno.10275, 2016.

Schaefer, H., Mikaloff-Fletcher, S. E., Veidt, C., Lassey, K. R., Brailsford, G. W., Bromley, T. M., Dlubokencky, E. J., Michel, S. E., Miller, J. B., Levin, I., Lowe, D. C., Martin, R. J., Vaugn, B. H., and White, J. W. C.: A 21st century shift from fossil-fuel to biogenic methane emissions indicated by ${ }^{13} \mathrm{CH}_{4}$, Science, 352, 80-84, https://doi.org/10.1126/science.aad2705, 2016.

Schlegel, M. E., McIntosh, J. C., Bates, B. L., Kirk, M. F., and Martini, A. M.: Comparison of fluid geochemistry and microbiology of multiple organic-rich reservoirs in the Illinois Basin, USA: Evidence for controls on methanogenesis and microbial transport, Geochim. Cosmochim. Ac., 75, 1903-1919, https://doi.org/10.1016/j.gca.2011.01.016, 2011.

Schneising, O., Burrows, J. P., Dickerson, R. R., Buchwitz, M., Reuter, M., and Bovensmann, H.: Remote sensing of fugitive emissions from oil and gas production in North American tight geological formations, Earth's Future, 2, 548-558, https://doi.org/10.1002/2014EF000265, 2014

Schoell, M., Lefever, J. A., and Dow, W.: Use of maturity-related changes in gas isotopes in production and exploration of Bakken shale plays, AAPG Search and Discovery Article no. 90122 (C2011, AAPG Hedberg Conference, 5-10 December 2010, Austin, Texas, available at: http://www.searchanddiscovery.com/ abstracts/pdf/2011/hedberg-beijing/abstracts/ndx_schoell.pdf (last access: 27 June 2019), 2011.

Schwietzke, S., Sherwood, O. A., Bruhwiler, L. M. P., Miller, J. B., Etiiope, G., Dlugokencky, E. J., Michel, S. E., Arling, V. A., Vaughn, B. H., White, J. W. C., and Tans, P. P.: Upward revision of global fossil fuel methane emissions based on isotope database, Nature, 538, 88-91, https://doi.org/10.1038/nature19797, 2016.

Sherwood, O. A., Schwietzke, S., Arling, V. A., and Etiope, G.: Global Inventory of Gas Geochemistry Data from Fossil Fuel, Microbial and Burning Sources, version 2017, Earth Syst. Sci. Data, 9, 63-656, https://doi.org/10.5194/essd-9-639-2017, 2017.

Shindell, D.: The social cost of atmospheric release, Climatic Change, 130, 313-326, https://doi.org/10.1007/s10584015-1343-0, 2015.

Shindell, D., Kuylenstierna, J. C., Vignati, E., van Dingenen, R., Amann, M., Klimont, Z., Anenberg, S. C., Muller, N., Janssens-Maenhout, G., Raes, R., Schwartz, J. Falvegi, G., Pozzoli, L., Kupiainent, K., Höglund-Isaksson, L., Emberson, L., Streets, D. Ramanathan, V., Kicks, K., Oanh, N. T., Milly., G., Williams, M., Demkine, V., and Fowler, D.: Simultaneously mitigating near-term climate change and improving human health and food security, Science, 335, 183-189, https://doi.org/10.1126/science.1210026, 2012. 
Tilley, B. and Muehlenbachs, K.: Isotope reversals and universal stages and trends of gas maturation in sealed, selfcontained petroleum systems, Chem. Geol., 339, 194-204, https://doi.org/10.1016/j.chemgeo.2012.08.002, 2013.

Tilley, B., McLellan, S., Hiebert, S., Quartero, B., Veilleux, B., and Muehlenbachs, K.: Gas isotope reversals in fractured gas reservoirs of the western Canadian Foothills: Mature shale gases in disguise, AAPG Bull., 95, 1399-1422, https://doi.org/10.1306/01031110103, 2011.

Townsend-Small, A., Marrero, J. E., Lyon, D. R., Simpson, I. J., Meinhardi, S., and Blake, D. R.: Integrating source apportionment tracers into a bottom-up inventory of methane emissions in the Barnett shale hydraulic fracturing region, Environ. Sci. Technol., 49, 8175-8182, https://doi.org/10.1021/acs.est.5b00057, 2015.

Turner, A. J., Jacob, D. J., Benmergui, J., Wofsy, S. C., Maasakker, J. D., Butz, A., Haekamp, O., and Biraud, S. C.: A large increase in US methane emissions over the past decade inferred from satellite data and surface observations, Geophys. Res. Lett., 43, 2218-2224, https://doi.org/10.1002/2016GL067987, 2016.

Turner, A. J., Frankenberg, C., Wennber, P. O., and Jacob, D. J.: Ambiguity in the causes for decadal trends in atmospheric methane and hydroxyl, P. Natl. Acad. Sci. USA, 114, 5367-5372, 2017.

Vaughn, T. L., Bella, C. S., Picering, C. K., Schwietzke, S., Heath, G. A., Pétron, G., Zimmerle, D. J., Schnell, R. C., and Nummedal, D.: Temporal variability largely explains topdown/bottom-up difference in methane emission estimates from a natural gas production region, P. Natl. Acad. Sci. USA, 115, 11712-11717, https://doi.org/10.1073/pnas.1805687115, 2018.
Whelan, J. K., Oremland, R., Tarata, M., Smith, R., Howarth, R., and Lee, C.: Evidence for sulfate reducing and methane producing microorganisms in sediments from sites 618, 619, and 622, Reports of the Deep-Sea Drilling Project, 47, 767-775, https://doi.org/10.2973/dsdp.proc.96.147.1986, 1986.

Worden, J. R., Bloom, A. A., Pandey, S., Jiang, Z., Worden, H. M., Walter, T. W., Houweling, S., and Röckmann, T.: Reduced biomass burning emissions reconcile conflicting estimates of the post-2006 atmospheric methane budget, Nat. Commun., 8, 2227, https://doi.org/10.1038/s41467-017-02246-0, 2017.

Wunch, D., Toon, G. C., Hedelius, J. K., Vizenor, N., Roehl, C. M., Saad, K. M., Blavier, J.-F. L., Blake, D. R., and Wennberg, P. O.: Quantifying the loss of processed natural gas within California's South Coast Air Basin using long-term measurements of ethane and methane, Atmos. Chem. Phys., 16, 14091-14105, https://doi.org/10.5194/acp-16-14091-2016, 2016.

Zumberge, J., Ferworn, K., and Brown, S.: Isotopic reversal ("rollover") in shale gases produced from the Mississippian Barnett and Fayetteville formations, Mar. Petrol. Geol., 31, 43-52, https://doi.org/10.1016/j.marpetgeo.2011.06.009, 2012. 